Studia Anglica Posnaniensia 50/2-3, 2015

doi: 10.1515/Stap-2015-0024

\title{
EPISTEMIC DISOBEDIENCE AND DECOLONIAL HEALING IN NORMA ELÍA CANTÚ'S CANÍCULA
}

\author{
MAEGORZATA POKS
}

University of Silesia

\begin{abstract}
Using the U.S.-Mexican border as the place of enunciation, Cantú's autoethnobiographical novel insists on the materiality of the border, especially for those living on its southern side, while simultaneously deconstructing it as artificial - a line splitting families and assigning nationalities on an arbitrary basis. Being a collage of photographs from the time the writer was growing up in southern Texas and the cuentos inspired by these visuals, Cantú's Canícula documents how border crossings and re-crossings become symptomatic of living in a liminal space and how they destabilize the concept of nationality as bi-national families must learn to live with ambiguity. On the one hand, there is the undeniable materiality of the border, with its pain, fear, deportations, and other discriminatory practices; on the other, there is a growing border community of resistance cultivating the memory that they are not immigrants, that they lived in Texas before the Guadalupe-Hidalgo treaty. The paper examines the community's strategies of survival in the contested cultural and social space and advances the thesis that, giving her community an awareness of its homogeneity and reclaiming its place within the larger socio-political context, Cantú becomes an agent of empowerment and change. She helps decolonize knowledge and being.
\end{abstract}

Keywords: U.S.-Mexican border, autoethnobiographical novel, Canícula, Norma Elia Cantú, Chicana literature

The transcendental subject - de-racialized, de-sexualized, and gender neutral was born after 1492, in the era of Europe's territorial expansion into the New World. The white European (later Euro-American) male was assumed to be the measure of humanity, from which other, non-Western peoples were excluded as inferior, underdeveloped, primitive, and therefore defined as obstacles to modernist progress and in need of conversion to the Christian religion and the capitalist economy of the "civilized" world. What legitimized the new colonial 
world order was the unexamined racial and patriarchal foundation of knowledge, assumed to be objective and universally valid although produced by one particular ethnic group in one particular geographical location. As argued by Walter D. Mignolo, the central figure in contemporary debates about decoloniality, "[t]he locus of enunciation from which inclusion is established is always a locus holding the control of knowledge and the power of decision across gender and racial lines, across political orientations and economic regulations" (Mignolo 2011: xv).

To shift the geography of knowledge from the mythical "zero point" of Western epistemology to the other side of the colonial difference, to admit that thinking does start with the body - racialized, geo-politically located, marked by a history of discrimination and oppression - is to question the very foundations of the colonial matrix of power. ${ }^{1}$ This questioning would be impossible without epistemic de-linking, that is detachment from the logic of modernity, which allows for a critique of the naturalized assumptions about the world. ${ }^{2}$ It is from a geo- and bio- politically marked site of enunciation that the ethnocentrism of modernity/coloniality becomes visible. Delinking (Spanish desprendimiento) from the "hubris of the zero point" 3 to unveil the rhetoric and promises of modernity/coloniality, reclaim suppressed epistemologies, and build pluriversal futures based not on individual success and abstract progress but on the fullness of life for all is what Mignolo terms decolonial thinking or epistemic disobedience.

Since the decolonial subject, located at the border of Western and non-Western knowledges, engages with the world from the places and historical experiences of her or his body (the Cartesian "I think therefore I am" is displaced by the formula "I am where I do and think"4), decolonial thinking is necessarily a form of border thinking. To think decolonially is to think from the borders of languages, religions, epistemologies; it is to think from what W.E.B. du Bois and Frantz Fanon theorized as double consciousness ${ }^{5}$ and Chicana writer and

1 Patrón colonial de poder, a concept introduced by a Peruvian sociologist Aníbal Quijano, denotes four interrelated spheres of management and control of the colonized "other": economy, authority, gender and sexuality, and knowledge and subjectivity (Mignolo 2011: 8).

2 Postcolonialism and postmodernism, as Mignolo repeatedly stresses, being critical towards modernity, still remain within its logic.

3 This concept was introduced by the philosopher Santiago Castro-Gómez in his La Hybris del Punto Cero. Ciencia, raza e ilustración en la Nueva Granada (1750-1816) (Bogota: Pontificia Universidad Javeriana, 2005).

$4 \quad$ See, e.g., Walter Mignolo, "I am Where I Do: Remapping the Order of Knowledge" (2011: 78117).

5 W. E. Burghardt Du Bois, The Souls of Black Folk: Essays and Sketches (Chicago: A. C. McClurg \& Co, 1903); Frantz Fanon, Peau noire, masques blancs (Paris: Éditions du Seuil, 1952). 
activist Gloria Anzaldúa called the consciousness of the mestiza. Anzaldúa's semiautobiographical Borderlands/La Frontera: The New Mestiza (first published in 1987) was an important inspiration for Mignolo's conceptualization of border thinking or border gnosis, which he defines as "knowledge from a subaltern perspective (...) conceived from the exterior borders of the modern/colonial world system" (...) (Mignolo 2000: 11-14). Placing herself at the intersection of the three traditions that shaped her: Anglo-American, Spanish-American and Nahuatl, Anzaldúa articulated a political hermeneutic which incorporates the perspectives, memories and experiences of the subaltern subject who dwells in the colonial wound. Moreover, in contrast to discursive formations which assume masculinity as being constitutive of all cultural categories, Anzaldúa highlights the potential of languages and sexualities, understood decolonially, to create a space in-between as a form of thinking otherwise. "La mestiza," writes Anzaldúa, "constantly has to shift out of habitual formations; from convergent thinking, analytical reasoning that tends to use rationality to move toward a single goal (a Western mode), to divergent thinking, characterized by movement away from set patterns and goals and toward more whole perspective, one that includes rather than excludes" (Anzaldúa 1999: 101).

The inclusive perspective of mestiza consciousness is both "a source of intense pain" and the beginning of healing of "the split that originates in the very foundation of our lives" (Anzaldúa 1999: 102). In an interview for Decolonization: Indigeneity, Education \& Society, Mignolo describes the process of healing the colonial wound in terms of "delinking, or regaining your pride, your dignity, assuming your entire humanity in front of an un-human being that makes you believe you were abnormal, lesser, that you lack something. How do you heal that? Through knowing, understanding, decolonial artistic creativity and decolonial philosophical aestheSis ${ }^{6}$, and above all by building the communal" (Gaztambide-Fernández 2014: 207). Thus defined, decolonial healing is a communal enterprise intended to "help the [wounded] person to survive in their marginalized communities, which are not the urban middle class" (GaztambideFernández 2014: 207). To build a world in which other worlds are possible, a pluri-versal, transmodern world in which reciprocity and solidarity are the main forms of social interaction, the narrow protocols of Reason are insufficient. The

6 Decolonial thinkers need to delink from Philosophical Aesthetics, which is the theory of the beautiful and sublime, since it is irrelevant to the billions of people not exposed to secondary education, and return to the original meaning of the Greek word aesthesis, which refers to the senses and the emotions derived from them. For Mignolo, decolonial aestheSis, unlike a particular aestheTics, refers to the dimension of the senses of every living organism and is geared toward decolonizing the senses (Mignolo, in an interview with Gaztambide-Fernández, 2014: 201-202). 
critique of modernity/coloniality must come from the outside, from a perspective that changes the terms of the conversation. ${ }^{7}$

The goal of this article is to demonstrate that Norma Elia Cantú's fictionalized memoir Canicula: Snapshots of a Girlhood en la Frontera, published in 1995 , both exemplifies the practice of epistemic disobedience and gestures toward decolonial healing. At first, I am going to introduce Cantú and the genre of autoethnobiography within which she has chosen to inscribe her text, paying special attention to the ways in which "truth" in the singular is relativized once the enunciator becomes geopolitically located in a cultural borderland. Emphasis will be put on illustrating how the border genre of autoethnobiography enacts, on the level of form and content, the clash and coexistence of various epistemologies, which for those trapped in the colonial wound is both destabilizing and liberating. The major part of the article will be devoted to the border community's practice of epistemic disobedience as depicted in Cantú's Canicúla. In the process of remembering the collective past and striving toward a future open to all, the community of Laredo/Nuevo Laredo is re-membered; it grows into a community of resistance to the capitalist idea of progress and the attendant fiction of modern universality. A community is formed and re-formed every time its history is told. The colonial discourse is contested by personal recollections and local knowledges reclaimed from the realm of tradition, popular thinking, myth, even witchcraft. In the process, members of the community regain their self-worth and the colonial world is healed, at least for a while.

\section{Norma Cantú: Living and Writing en la frontera}

Norma Elía Cantú, born in Nuevo Laredo, Mexico, and brought up on the other side of the border, in Laredo, Texas, has been formed by that borderland's diverse cultural traditions: Anglo, Latino/a, and Native American. As professor of English at the University of Texas in San Antonio, poet, novelist, folklorist and teacher, she frequently blurs distinctions between scholarship and creative writing, engaging interchangeably in what she calls "activist scholarship" and "scholarly activism" (Merman-Jozwiak and Sullivan 2009: 134). Thus, in her ethnographic research on the Christmas shepherd's play called pastorela,${ }^{8}$ the Laredo religious ritual of the Holy Cross performed by dancers in Indian costumes,

7 Mignolo's term. He uses it to signal that decolonizing options cannot remain within the logic of modernity.

8 Norma Cantú, The Offering and the Offerers: A Generic Illocation of a Laredo "Pastorela" in the Tradition of Shepherds' Plays. (SPAIN, MEXICO, TEXAS) (January 1, 1982). ETD collection for University of Nebraska - Lincoln. Paper AAI8306475. http://digitalcommons. unl.edu/dissertations/AAI8306475. 
known as the Matachines, ${ }^{9}$ or the cultural practices of Latin@ communities, like la quinceañera,${ }^{10}$ the coming-of-age ritual, Cantú uses the border as the place of enunciation, integrating her own experience into the research, a standard practice for decolonial scholars.

This blending of ethnographic and autobiographical perspectives is also visible in her first novel, Canicúla: Snapshots of a Girlhood en la Frontera. Warning the reader that the events recorded in the novel "are completely fictional, although they may be true in a historical context" (Cantú, Canicúla xi), the author roots recollections of her childhood and young adulthood in a larger cultural context attempting to depict the life of the Chicano community in which she grew up. Thus, her fictional autobiography becomes an "autobioethnography." Cantú explains: "although it may appear that these stories are my family's, they are not precisely, and yet they are. But then again, as Pat Mora claims, life en la frontera is raw truth, and stories of such life, fictitious as they may be, are even truer than true" (Cantú, Canicúla xi).

\section{Truer than True: The Politics of Auto(bio)ethnography}

In 1992 Mary Louise Pratt, Professor of Spanish and Portuguese Languages and Literatures at New York University, published Imperial Eyes: Travel Writing and Transculturation. In that book she coined two important terms. The first one, "contact zones," or spaces of colonial encounter in which colonizers and colonized interact with each other in highly asymmetrical power relations, is roughly synonymous with borderlands. The other term, "autoethnography" refers "to instances in which colonized subjects undertake to represent themselves in ways that engage with the colonizer's terms. If ethnographic texts are a means by which Europeans represent to themselves their (usually subjugated) others, autoethnographic texts are those the others construct in response to or in dialogue with those metropolitan representations" (Pratt 2008: 7). Written from the other side of the colonial difference, autoethnographies incorporate both indigenous and metropolitan idioms, they also borrow some stylistic or generic conventions from imperial/colonial texts to appeal to metropolitan modes of understanding. Moreover, they often involve collaboration between a semi-literate native and a Western intellectual, as was the case of early slave narratives.

In Spanish America, Pratt continues, the earliest autoethnographic text, Nueva Cronica y buen govierno y justitia, was written in 1613 by an Inca, Guaman Poma

9 Norma Cantú, "Soldiers of the Cross: Los Matachines de la Santa Cruz. » Unpublished book manuscript.

10 Norma Cantú, "La Quinceañera: Towards an Ethnographic Analysis of a Life-Cycle Ritual.” www.tamiu.edu/necantu/quincean.htm. Laredo, TX, 1996. 
de Ayala, who had adopted Christianity and knew some Spanish. Guaman Poma adapted the conquerors' genre of writing, the chronicle, to critique the invaders' exploitation and abuse of the indigenous population, the grave failures of their administration, and the inability to create a just government. The New Chronicle and Good Government and Justice was addressed to the Spanish king and advised him how to reform the empire. Pratt writes: "Guaman Poma mirrors back to the Spanish (in their language, which is alien to him) an image of themselves that they often suppress and will therefore surely recognize. Such are the dynamics of language, writing, and representation in contact zones" (Pratt 1999).

If autoethnography is a representation of a subaltern community written from the perspective of decoloniality by a person who identifies with that community's traditional way of life, autobioethnography, by analogy, might be understood as a form of life-writing that focuses on an individual as representative of and embedded in a culture of a subordinate ethnic group. Ellen McCracken defines it as "a creative new genre that merges [...] both fictional and veridical account of the self and community" (2001: 5). Being a form of border writing, it adapts the canonical genre of Western autobiography but transcends generic classifications and dislodges epistemological certainties by fusing verifiable facts (the Western regime of knowledge) with community beliefs and memories lodged in the colonized bodies. In Hispanic America this often takes the form of testimonial texts, or testimonios. Many critics of the genre have pointed out the difference between the testimonio's collective representation of the historically oppressed, the majority of whom are women, and the canonical Western text, with its focus on a singular individual, who is usually male, white, and educated. According to John Beverley:

\footnotetext{
Testimonio is a fundamentally democratic and egalitarian form of narrative in the sense that it implies that any life so narrated can have a kind of representational value. Each individual testimonio evokes an absent polyphony of other voices, other possible lives, experiences. Thus, one common formal variation on the classic firstperson singular testimonio is the polyphonic testimonio, made up of accounts by different participants in the same event. (Beverley 2004: 34)
}

In the last decades of the 20th century testimonio emerged as a powerful mode of indigenous women's writing. Traditionally silenced by canonical versions of history, subalternized women have begun presenting their versions of "truth," rescripting history and challenging authoritarian power. Me llamo Rigoberta Menchú y así me nació la conciencia (1983), translated into English as I, Rigoberta Menchú, An Indian Woman in Guatemala (1984) has become a classic text within this genre. Moreover, it sparked a heated debate about the truth value of the autobiographical narrative.

In Rigoberta Menchú and the Story of All Poor Guatemalans (published in 1999), U.S. anthropologist David Stoll charged the indigenous activist and 1992 
Nobel Peace Prize winner with lying about her past, and more exactly, with introducing inaccuracies and distortions of objective facts in her memoir. The Stanford educated Stoll who received his doctorate in 1992, at the height of the American "culture wars" (Pratt 2001: 31), misread the Menchú testimonial by interpreting it through the ideological lens, as an effort to both exalt the guerrilla movement and enhance the atrocities committed against that country's civilian population by the CIA-supported Guatemalan government. In an article under the illuminating title "When Truth is at stake: The Rigoberta Menchú Controversy" (2010), Ragnhild Solvi Berg highlights the necessarily subjective aspect of testimonios emerging from the unstable political context of Central America. Contemporary Guatemalan history, as Berg notices, has been rife with violence, and the country has suffered from political and economic instability. Ruled since the mid-nineteenth century by a series of dictators favouring the U.S.A.'s neo-colonial policy, shaken by left- and right-wing military coups, between 1960 and 1996 the country suffered from a bloody civil war which included massacres of the Mayan population. Whether, however, the latter were "justified" by the fact that the indigenous peasants supposedly sheltered rebels, or discredited as acts of wanton and unjustifiable cruelty depends on one's geo-and bio-political location. Berg asserts: "Whatever you believe is the answer will reveal all about your political standpoint, and hence also might reveal your origin, education and economic standing. It is therefore complicated to represent the 'facts' in Guatemalan history" (2010).

Moreover, David Stoll's challenge of Menchú's "guerrillaphile interpretation of the war,"11 issued from his own situatedness in the "zero point" of epistemic privilege (white, Anglo-American, anthropologist), failed to take account of the non-Western, Maya storytelling tradition, especially the close connection between the individual and the communal in traditional cultures. More than an isolated story, the testimonio of Rigoberta Menchú, as Berg points out, represented the experience of the entire people and revealed their desperate struggles to the outside world. Arturo Arias of the University of Texas at Austin agrees that Stoll read Manchú "out of context." Arias claims:

By eliminating Menchú's own articulation of power and how it is linked to the specific political contingency of a heterotopical space named "Guatemala," Stoll invests Menchú with a different reality. In Stoll's new reading, ${ }^{12}$ she becomes the phantasm of a Communist liar. By insinuating that Menchú's signifiers are brimming with ide-

\footnotetext{
11 This is how Stoll calls Menchú's memoir. See David Stoll's academic profile available at http://www.middlebury.edu/academics/es/faculty/node/25831.

12 David Stoll, "The Battle of Rigoberta," The Rigoberta Menchú Controversy. Eds. Arturo Arias, David Stoll (Minneapolis: University of Minnesota Press, 2001).
} 
ologems that make her ethnicity redundant, he conveniently forces her into the stereotype of the devious, conniving person of color. ... Indeed, we could claim that the Rigoberta Menchú controversy is not one about what Menchú said, that part of it is an imaginary act. Rather, it is a symbolic lesion (lesson?) about the unwillingness of hegemonic intellectuals to listen to subaltern ones (Arias 2002: 481).

In a similar fashion, Walter Mignolo criticizes Rigoberta Menchú's critics for thinking from a denotative and territorial epistemology, while the Mayan woman "argues from an enactive and border epistemology" (2000: 26). Subaltern epistemologies are performative and transformative, Mignolo argues further; they emphasize the will to transform reality. Ultimately, decolonial thinking aims at producing knowledges capable of building worlds in which life as such takes precedence over economic and military gains.

The memoir of Rigoberta Menchú has been recognized as foundational for border thinking (Mignolo 2000: 166) and the controversy it sparked among conservative Western scholars only confirms this status. Obviously, when borderlands become sites of enunciation, the question of language and cultural translation come to the fore of attention. In view of the fact that since the Renaissance and the Enlightenment the enunciative privilege has historically belonged to the six modern European languages ${ }^{13}$ considered apt for rational thinking, Menchú could not have made her voice heard in her native Quiché-Maya, and her inadequate command of Spanish made her rely on an editor form the other side of the colonial difference ${ }^{14}$ who could legitimate her story. Additionally, while the memoir's original, Spanish version was entitled Me llamo Rigoberta Menchú y asi me nació la conciencia, ${ }^{15}$ the English translator missed the title's political message and opted for an aggressively individualistic title, I, Rigobeta Menchú, more characteristic of the First World's Protestant culture than expressive of the spiritual and community-oriented values of the Maya. Thus, the Anglo-Saxon world's "exultation of the first person" (Mignolo 2011: 108) distorts the testimonio's explicit intention to give voice to the indigenous peasants and document the birth of political consciousness among the oppressed. Translations do not travel easily across various regimes of knowledge.

\section{Thinking and Speaking from the Border: Canicúla}

The Rigoberta Menchú testimony, combining ethnography and memory, mixing "fact" and "fiction" to enhance a larger truth, decolonize narratives, and redress the subalternization of knowledge can be seen as a yardstick against which to

\footnotetext{
Languages of the colonizing nations: Spanish, English, Portuguese, French, German, and Italian. The memoir was transcribed and edited by Venezuelan-French anthropologist Elisabeth Burgos. Literally: I am Rigoberta Menchú and this is how my (political) consciousness was born.
} 
measure Norma Cantú's autobioethnography set on another problematic border the frontera between Mexico and the United States of America. This site of enunciation has had its own history of lawlessness, violence and discrimination against its non-Anglo inhabitants. In 1848 a substantial part of Mexico was forcefully incorporated into the U.S.A and the border between those two countries was established on the Rio Grande / Río Bravo River. Ever since, the borderland has been the site of armed uprisings, forced deportations, legal and illegal migrations, narco- and human trafficking, gendered violence, and other varieties of border troubles. As for families separated by the frontera, border crossings and re-crossings have become symptomatic of living in a liminal space characterized by repression, ambiguity and contradictions.

The inscription of Cantú's Canicúla (1995) within border epistemology is confirmed by this opening epigraph, a quotation from Gloria Anzaldúa's canonical Borderlands / La Frontera: "The U.S.-Mexican border es una herida abierta where the Third World grates against the first and bleeds." Norma Cantú's story of a "girlhood en la frontera," narrated from the "open wound" (herida abierta), the conflicted space where two diverse worlds collide, is told by a young woman, Nena/Azucena Cantú, who, like Norma, was born in Nuevo Laredo to a family of mixed Mexican American heritage and brought up in Laredo, on the U.S. side of the border.

Arguably, the narrative's contestation of stable meanings begins on the level of aestheSis: upon opening the book the reader's eye is attracted by a hand-drawn map of the border region depicting places mentioned in the narrative and questioning the border's practical validity. Other visuals, in the form of 23 photographs (the "snapshots" of the subtitle) are interspersed with the 85 verbal vignettes. Thus, rather than a "regular" book, Canicúla is introduced as an "irregular" text consisting of a collage of photographs and stories. Moreover, although the photographs are authentic and document the author, Norma Cantú's childhood and young adulthood, the story is not strictly autobiographical, not every story is paired with a photo, and not every description is faithful to the corresponding picture. To give one telling example, it is easy to accept the narrator's identification documents reproduced in figures 3 and 4 as authentic. Upon closer observation, however, one notices that on both documents the handwritten signature, in the unmistakable handwriting of the author, identifies the owner as Azucena Cantú, while the photographs stapled to them are those of Norma Cantú as a one-year-old baby and an adolescent respectively. What could be assumed to be another strategy of enhancing the communal experience in the "autbioethnobiographic" genre (its representative character justifies the collapsing of identities) proves to be indefensible once the reader realizes that a baby girl (figure 3 ) could not possibly have signed her name; in addition, the signature is in an adult's 
handwriting and is identical on both documents. Ellen McCracken of the University of California observes that these "signatures tease us to uncover the adult Cantú's 'forgery' of her own documents in the hybrid visual/verbal border crossing of this book" (2001: 272). Questioning traditional signifiers of (Western) identity, Canicúla suggests that traditional (non-Western) communities draw their sense of identity not from abstract papers but from the lived experience of belonging and co-existing.

Another example of destabilizing classical Western conventions is the fact that, as Cantú explains in the Introduction to Canicúla, that book is not the first but the middle part of a planned trilogy that focuses on several generations of a family living in the Mexican-U.S. borderland (Canicúla, xi). Given the fact that none of the remaining two has come out since 1995, when she first made that claim, McCracken has advanced the theory that the author's assertion is still another strategy meant to destabilize the truth claim implicit in the autobiographical genre (2001: 6). Although this theory does not seem credible, ${ }^{16}$ it illustrates the difficulty in separating "truth" from "fiction" in Cantú's unsettling border narrative.

Despite some appearances to the contrary, the expressed intention of Norma Cantú is to eventually get the entire trilogy published. Interestingly, the trilogy's first part is supposed to have been written entirely in Spanish, the language spoken by the majority of Mexican Americans between the 1880s and 1950s, the time of the narrative. True to its title, Papeles de mujer is told through the medium of letters and authentic documents, but it is legitimate to expect that the "authenticity" of those papeles may turn out to be equally questionable as the autobiographical value of Canicúla. The final part, Cabañuelas: A Love Story, will be set in the late 1990s and, judging by the title, will be written in Spanglish, or at least with a significant presence of code-switching, the authentic expression of turnof-the-twentieth-century Chican@ culture, which may prove difficult to follow for non-Spanish readers. Yet, Cantú will not betray the culture she speaks for and from to please the metropolitan reader. She already refused to heed her prospective publishers' advice to rewrite Canicúla in either English or Spanish to make it more publishable. Although the repeated rejections of the text resulted in the novelist's sense of a "linguistic exile" (Cantú, qtd. in Gutierrez Y Muhs 2007: 35), Cantú was determined not to allow "the wild tongue" of the border to be "tamed." "[A]s long as I have to accommodate the English speakers rather than have them accommodate me, my tongue will be illegitimate," wrote Anzaldúa in her famous essay "How to Tame a Wild Tongue" (Anzaldúa 1999: 81). Rather than translating - which would mean that Chicanos/as still need to "beg entrance"

16 Cantú's current professional CV specifies the status of those two unpublished books as either "under review" (Papeles de mujer) or "work in progress" (Cabañuelas). http://cas.umkc.edu/latino-studies/people.cfm. 
into the Anglo culture - Cantú took to heart Anzaldúa's demand that they be "met halfway" (Anzaldúa, preface). In consequence, Cantú was among the first Chicana writers to have introduced Spanglish as a "legitimate" tongue and to have given a recognizable, postnational identity to her borderland community.

As argued by Mignolo, border identities need to be expressed in border tongues - the tongues which emerged in response to colonization from both sides. "Ethnic identity is twin skin to linguistic identity - I am my language," declared Anzaldúa (1999: 81). In Canicúla, as Castillo and Tabuenca Córdoba observe, the Spanish language and Mexican culture continuously disrupt the English-language, US-based narrative in Nena's difficult negotiation between two monolinguistic territories (1995: 117). Spanglish, the living idiom of her border community, transcends the boundaries of language understood as a sign system. Rather than a linguistic system, it is a lived reality, a process, and a whole way of being. It is languaging. In Local Histories / Global Designs: Coloniality, Subaltern Knowledges, and Border Thinking, Mignolo defines languaging as thinking and writing between languages and a process of social transformation. Having transcended the official languages of colonial empires, languaging invents new strategies for manipulating social domains of interaction (2000: 226-27). It is obvious that language has always been an instrument of empire building. The imposition of rules of grammar that are to be universally accepted mirrors, on the metaphorical level, the total political and economic control wielded by the empire over colonized subjects. Languaging, argues Mignolo, fractures colonial languages. Revealing the ideology of speaking and writing in one language, it becomes a fundamental condition of border thinking (2000: 253).

\section{Epistemic Disobedience and Decolonial Healing in Canicúla}

Memories are incomplete and unreliable. This is why in Cantú's narrative the act of recollection is collective and highly subjective. The adult Azucena/Nena and her mother retrieve old shoeboxes packed with family photographs. They pick one photograph after another at random and recollect the family's history. "For days, for weeks, for months, they hold the photographs reverently, and the stories come to them" (Cantú, Canícula 2). Sometimes the younger sisters contribute their recollections of a scene, an image, and the emotions associated with them; sometimes the father "curious, interrupts"; mostly, however, it is Nena and her mother who weave the tales, "the mother filling in gaps for the daughter, of before, of the times before and during that she has forgotten, or changed in her mind - the family, the neighbors, celebrations, events. Some they both experienced yet remember differently; they argue amicably, each sticking to her version of what happened" (Cantú, Canicula 2). The resulting story is a series of random "snapshots," a patchwork, a collage of a culture and a narrative that is like a patchwork. 
"The stories of her girlhood in that land in-between, la frontera, are shared," writes Cantú, "her story and the stories of the people who lived that life with her is one" (Canicúla, 2). The real protagonist of the novel is "we," the community. The vicissitudes of the lives recollected contradict the fixity of material and metaphorical borders.

Thus, for instance, from the old shoeboxes Nena retrieves a photograph of her mother as a young woman dressed in a traditional Mexican dress called China Poblana, with the Mexican symbol on it: an eagle clutching a snake. "She who wasn't even born in Mexico, who went there as a ten-year-old knowing only to read and write in English" (Canicúla, 40), wonders the daughter as she contemplates the photo. Identity in the borderland is fluid and processual. It is a question and an on-going challenge. Soon the mother learned Spanish and forgot her English. When she re-crossed the border at twenty, she was married to a Mexican rancher who had earned enough money as a contract labourer in the U.S. to move his wife and little daughter "to the US side, but not too far north, not too far from the family" (Canicúla, 29). The little Nena, who could not speak proper English until her first school year, never learned "school" Spanish either. During one of her summer visits with her tía and Mamagrande, the maternal grandmother, in Monterrey, she studies to be a beautician. She passes her exams, but the ortografía of her "nonschool learned Spanish is found lacking" (Canicúla, 128). Part Anglo, part Mexican, the Chican@ is both and none at the same time.

Border crossings, in the literal and metaphorical sense, are part of the Cantú family's everyday life. They cross from Laredo to Nuevo Laredo to do shopping, to visit, to attend family celebrations, to go on holiday. For the purpose of crossing the border, the one-year-old Nena was issued U.S. immigration papers. Curiously, they identified her as a white Mexican citizen, while at the age of 16 the word in her filiacion papers defining her skin colour is moreno (dark) (Canicúla, 22). Living on the border is charged with contradictions and colonial markings. When the little child was asked by her Mexican cousins to say something in English, she recited what all U.S. children know by heart: nursery rhymes, the pledge of allegiance to the flag, and she sang "Old MacDonald." But as soon as the kids tired of her English and returned to their Mexican games and Spanish-language talk, Nena felt an outsider. Back in Texas, she played cowboys and Indians on the model of American westerns and even wrote her first imaginative story with a heroic cowboy figure and Indian villains in it. "All the while," she comments from her adult-life perspective, "my uncles in Anáhuac herding cattle and being real cowboys, my aunts living out stories no fifties scriptwriter for Mexican movies or US TV ever divined" (Canicúla, 34). Like the whole border community, Nena was shaped by the colonial matrix of power. The most powerful cultural medium - the TV - imprinted the dominant culture's images on the impressionable young mind. The image became reality while real experience was discredited, its imaginative potential invalidated 
for years to come. In her later life Nena will have to disentangle herself from the internalized sense of "Anglo" cultural superiority. Her attempt at decolonizing her adult self will take the form of epistemic disobedience. Realizing that knowledge is an instrument of colonization, she will have to question Western epistemological protocols first and decolonize them next by reclaiming ways of thinking otherwise - the forms of knowledge suppressed or excluded by the logic of coloniality.

Instrumental in this struggle will be Nena's revaluation of Chicana's real life stories - like the story of Cousin Elisa, which had much more dramatic potential than any Hollywood scriptwriter could have imagined way back in the 1950s. Seduced at sixteen and expelled from the house by Papagrande, Nena's paternal grandfather, the mother powerless to defend her own daughter, Elisa moved to L.A. to stay with Mamagrande's cousin, Andrea. The cousin had just left her older children on the Mexican side of the border and moved with her husband to California to seek medical help for their youngest son who had been diagnosed with leukemia and who eventually died at the age of seven. Meanwhile, Andrea's other children had grown up and started adult lives, denying the rigidity of "traditional" ways of being Chicanos/as: the daughter married an Iranian, left America and lavished all her passion on her kids; the son went to Cuba to fight in the Castro revolution. All the while Cousin Elisa worked day in and day out to raise her daughter but was deprived of the joys of motherhood, because Rosalinda, the daughter, was living with Elisa's parents in Nuevo Laredo. Nena knows that for Elisa "not to see her child grow, not to be there for her first step, or the first day at school, or to dry her tears when she fell, or to enjoy her laughter, [was] a far greater punishment as far as she was concerned than to be banished from Papagrande's house" (Canicúla, 77-78). Not before was her daughter safely married, did Elisa accept a marriage proposal, but even then she was busy working, keeping house, and cooking for her husband every day of the week. Nena sees the thwarted potential of beautiful Elisa's life, mourns the waste, refuses to embrace the ill-conceived idea of honour whose guardians are the family patriarchs, and celebrates the woman's dogged determination and motherly love which stops at no sacrifice. In the figure of Cousin Elisa, Nena/Norma pays homage to all the brave Chicanas whose silent suffering and patient love countered the violence and destruction of colonial and patriarchal oppression: the women that made survival possible. Canicula is a love song to a community bound by ties of love and homage to its women: the weavers of ties that bind, the seamstresses who patch up broken lives like patchworks - their signature artistic creation - the spinners of yarns which heal and teach endurance. "The feminist in me," comments the novelist in "The Writing of Canicúla," "consciously included the strong women - the mothers, grandmothers, aunts, comadres" (Cantú 2003: 105).

In an interview, Norma Cantú admitted to a lack of courage to be political in her life. To exorcise demons, "the guilt of not having done something," she is 
political in her writing (2004: 131). Gender politics is crucial to Canicúla. Redrawing the power line between genders, the novelist emphasizes the importance of sisterhood, of "women sharing life, tending to each other. Supporting each other" (Canícula, 36). When men fail or disappear, it is the women who take matters in their hands. Always on the spot, they show love by deeds, not words, and by everyday commitments, risking their lives, even reputations, to help. Bueli, Nena's maternal grandmother, had lost her mother at birth and her father worked far away from home. When a handsome Tejano courted Bueli, it was the grandmother who arranged the couple's elopement, against the uncles' explicit ban on admitting a foráneo to the family. "In a household of absent men what could she do?" (Canícula, 41), asks Nena the narrator, celebrating the women's determination and rebellious strength in the face of inept masculinity.

Equally important for Cantú is the community's fidelity to that "land in between cultures that [Nena] calls la frontera, the land where her family has lived and died for generations" (Canicúla, 2), a land situated "on both sides of a river that is never a barrier," a land which "lies beyond barriers" (Canicúla, 42). The materiality of the border is constantly under erasure for a family whose dead are buried on both sides and whose living constantly defy the frontier's existence. Mamagrande's Spanish ancestors settled in Monterrey before Mexico gained independence. She was brought up in a splendid mansion full of servants, married at 15, crossed the Rio Bravo River with her pacifist husband to escape the Mexican Revolution and re-crossed it again at the time of the First World War draft. Her children's graves are scattered on both sides of the border. For the family and the larger border community, the annual Day of the Dead is an opportunity to reclaim the problematic territory, to dismantle the artificial state barrier in celebrating a history that goes back to before the Guadalupe-Hidalgo Treaty. By the 1950s, Halloween, that strange US custom, is still alien to the Chicano women busy making wreaths, cleaning tombs, pulling out weeds, and fixing flower arrangements for the Day of the Dead, Día de los muertos. The women transmit and celebrate a culture formed by the border but resistant to borders, a culture which accommodates elements of Mexican and American culture, but differs from both. Thirty years on, going trick-ortreat would become common and a tall Frankenstein figure in full costume would be standing at the cemetery gate. "Día de los muertos had taken on a new meaning" (Canicúla, 74) to the returning Nena. Although Cousin Adela was still making her artistic wreathes, she now replaced the crepe paper flowers dipped in wax with more endurable plastic flowers much preferred by her younger customers (Canicúla, 73). "Our culture is a resistant culture," Cantú confessed and defined Canicúla as "a vision of that particular era in our history from the thirties to the sixties, of how our community survived" (Gutierrez Y Muhs 2007: 20). Asked what contribution Canicúla makes to the canon of Chicano/a literature, she responded: "that we survive because of our culture" (Gutierrez Y Muhs 2007: 20). 
The 1960s were turbulent times and la frontera and the cultural struggle became inextricably linked to racial politics of the Civil Rights era. The body of Tino, Nena's talented younger brother, returns from Vietnam in a casket. Nena joins rallies protesting the unjust war and marches in support of the striking farm workers in Delano. "[I] wonder what else I can do, a lowly office clerk," she recollects, "wear a César Chávez button, read Marx" (Canicúla, 31). Back in the 1950s, when the eight-year-old Nena observed how the corrupted politicians "abuse[d], rape[d], embarrass[ed], harass[ed], taunt[ed], demean[ed] women" and how they oppressed the poor, she wondered "what makes men so important." "At eighteen," she continues, "I can't forgive" (Canicúla, 31). Throwing her lot with Chávez's movement and his determined refusal to use violence, she embraces another model of masculinity, one more in keeping with the emerging consciousness: the consciousness of the border. Although absent from the novel otherwise than in the form of the allusion quoted above, the Movimiento led by César Chávez was a turning point in the politics of Chicano identity. When the striking farm workers debated the possibility of using violence as a more successful and purportedly more "manly" strategy of protest against the capitalist oppressor, Chávez responded with waging a hunger strike. "Non-violence is not inaction," he said. "It is not discussion. It is not for the timid or weak (...). Non-violence is hard work. It is the willingness to sacrifice. It is the patience to win ("Education of the Heart"). Nonviolence, one could add, is the strategy most oppressed Latinas had been using without knowing it: patient and strong, sacrificial and compassionate, they often loved their "manly" spouses and other stern father figures, physically stronger but psychically vulnerable, who believed manliness consisted in keeping their womenfolk in submission. While men, devoid of self-respect by colonial and racial oppression, needed to prove themselves in street fights, drunken brawls, and amorous adventures, their women carried on life as usual, laughing with their comadres even when there was nothing to laugh at; chatting about births, deaths, marriages; helping one another make ends meet; keeping houses, ironing, washing, cooking, raising children, and patiently hoping for better times. Transmitting values, creating a community, transforming the world with their love; making another world possible.

As soon as Chicanos admit their guilt and accept women as their equals, prophesied Gloria Anzaldúa, and as soon as they reclaim tenderness and vulnerability as essential traits of masculinity, a spell will be broken, a new reality will be possible, the day of the mestiza will dawn. "On that day," Anzaldúa writes, "I gather the splintered and disowned parts of la gente mexicana and hold them in my arms. Todas las partes de nosotros valen." On that day she says to Chicanas' former oppressors: "here we are weaponless with open arms, with only our magic. Let's try it our way, the mestiza way, the woman way" (Anzaldúa 1999: 110). Norma Cantú, a co-founder of The Society for the Study of Gloria Anzaldúa, 
knows what it means to live in the borderlands, but above all she knows that "to survive the Borderlands / you must live sin fronteras / be a crossroads" (Anzaldúa 1999: 217).

Decades before the Civil Rights movement, Nena's maternal grandparents had black and Chinese neighbours in San Antonio, Texas. Tía Nicha recollects that they "all lived together, those who worked for the railroad, in the same barrio. Like family. If one was in trouble the others helped" (Canicúla, 109). Dismantling the frontiers of race and forming alliances across racial divisions was a common practice among marginalized groups. But frontiers of religious dogma and accepted morality were crossed just as often. As a child Bueli lived next door to a real witch, a bruja, who practiced voodoo. Interestingly, seeing her daughter play with "homemade dolls with straight pins stuck all over their bodies" (Canicúla, 109) the girl had dug up in Doňa Remedios's yard, Bueli's orthodox Roman Catholic mother ordered the child to get rid of them immediately "or something terrible would happen" (Canicúla, 110). It is evident that in the borderlands sorcery was a well-established way of obtaining the desired results, just as prayer was. At times, one could be indistinguishable from the other, the Western and indigenous spiritualities blending seamlessly into each other. Papi's contract with Nuestra Seňora del Perpetuo Socorro is another case in point. Crediting her intercession with little Tino's recovery from a near fatal illness, he built her a home altar and lit candles to her with great veneration. Sixteen years later, after Tino's death in Vietnam, Papi tore the image off the wall, raging against the Virgin. "For this, you spared my son" (Canicúla, 15), he would ask bitterly, suggesting that the goddess-like Mother of God cheated on him.

\section{Conclusions}

The subtitle of Cantú's novel - Snapshots of a Girlhood en la frontera - with its explicit reference to Anzaldúa's Borderlands/ La Frontera, announces the novel's main epistemological and narrative trajectory: ambiguity, resulting from the perpetual clash of cultures in the borderlands, necessitates the abandonment of rigid habitual formations, a breaking down of dualities in the mestiza's struggle for a wider, all-inclusive consciousness tolerant of contradictions. To Anzaldúa, the move beyond dualism was to be "the beginning of a long struggle (...) that could (...) bring us to the end of rape, of violence, of war (1999: 102). It is clear that this decolonized consciousness can no longer be expressed in terms of linearity and narrative continuity characteristic of Western rationality. The constantly shifting perspectives and cultural frameworks of the borderlands dismantle the dual myth of the unitary subject and the reliable narrative. Formed by contesting cultures and linguistic codes, struggling to have their stories told from outside the centre of privilege, silenced and oppressed by the dual mechanism of patriarchy 
and colonialism, mestizas' life-writing contests the autobiographical canons established by and for white men. Chicana poet Berenice Zamora wrote in her essay "Silence at Bay" that "the mind of a woman whose life is at risk at all times in all situations is a mind far more sophisticated than single-leveled reasoning can assess, and so their writings require far more sophisticated literary approaches than are available to us today" (qtd. in Gutierrez Y Muhs 2007: xviii).

Discontinuous and fragmented as the bicultural, code-switching narrator's self-understanding, Cantú's autobioethnography argues that "we live our life in memories, with our past and our present juxtaposed and bleeding, seeping back and forth, one to the other in a recursive dance" (Canicúla, xii). In the border everything is in the state of transition and change; the recollecting subject reinvents the past through her repeated reinvention of self and other. As noticed by Castillo and Tabuenca Córdoba, "for the narrator, border crossing is both an everyday event and a passage into an available alternative definition of self and space" (2002: 114).

Reconceptualizing women's agency, depicting the family as a gendered site of social power, and overcoming the "tradition" of silence which denied voice to her non-white, non-English speaking community, Cantú, an organic part of her subaltern community, becomes an agent of social and cultural transformation for that community. The politics and aesthetics of her autobioethnography reflect and reinforce each other to evoke a life lived in "a destabilizing in-betweenness" (2002: 122). Her novel - juxtaposing words with photographs, mixing facts and fiction, and switching linguistic codes - consistently dismantles binary oppositions sanctioned by the modern/colonial consciousness and resists "the patriarchal and Anglocentric confinements of the term "American"' (2002: 3). Making the border her place of enunciation, the author decolonizes knowledge and transforms the local into the global. ${ }^{17}$

\section{REFERENCES}

Anzaldúa, Gloria. 1999 [1980]. Borderlands / La Frontera: The New Mestiza. San Francisco: San Lute Books.

Arias, Arturo. 2002. After the Rigoberta Menchú controversy: Lessons learned about the nature of subalternity and the specifics of the indigenous subject. Modern Language Notes 117 (2): 481-505.

Berg, Ragnhild Solvi. 2010. When truth is at stake: The Rigoberta Menchú controversy. Global knowledge: Research across boundaries. Ed. Runo Isaksen. SIU. (accessed 20 April 2015).

17 Among those who responded to the novel by identifying with it are Canadian-U.S. border communities and Afro-Americans who used to pick cotton (Beverley 2004: 132). 
Beverley, John. 2004. Testimonio on the politics of truth. Minneapolis: University of Minnesota Press.

Cantú, Norma Elia. 1995. Canícula: Snapshots of a girlhood en la Frontera. Albuquerque: University of Mexico Press.

Cantú, Norma Elia. 2003. The writing of Canicúla: Breaking boundaries, finding form. In Gabriela F. Arredondo, Aída Hurtado, Norma Klahn, Olga Nájera-Ramírez \& Particia Zavella (eds.) Chicana feminisms: A critical reader, 97-108. Durham, NC: Duke University.

Castillo, Debra A. \& María Socorro Tabuenca Córdoba. 2002. Border women: Writing from la Frontera. Minneapolis: University Press of Minnesota. Education of the Heart-Quotes by Cesar Chavez. United Farm Workers. ufw.org. (accessed 27 February 2015).

Gaztambide-Fernández, Ruben. 2014. Decolonial options and artistic/aestheSic entanglements: An interview with Walter Mignolo. Decolonization: Indigeneity, Education \& Society 3 (1): 196-212.

Gutierrez Y Muhs, Gabriella. 2007. Communal feminisms: Chicanas, Chileans, and cultural exile : Theorizing the space of exile, class, and identity. Lanham, MD: Lexington Books.

McCracken, Ellen. 2001. Hybridity and the space of the border in the writing of Norma Elia Cantú. Studies in 20th Century Literature 25 (1): 261-280.

Merman-Jozwiak, Elisabeth \& Nancy Sullivan. 2009. Testimonio, reconnection, and forgiveness. Conversation with Norma Elia Cantú. In Elisabeth Merman-Jozwiak \& Nancy Sullivan (eds.) Conversations with Mexican American Writers: Languages and Literatures in the Borderlands, 115-137. Jackson: University Press of Mississippi.

Mignolo, Walter. 2000. Local histories/Global designs: Coloniality, subaltern knowledges, and border thinking. Princeton, New Jersey: Princeton University Press.

Mignolo, Walter. 2009. Epistemic disobedience, independent thought and de-colonial freedom. Theory, Culture \& Society 26 (7-8): 1-23.

Mignolo, Walter. 2011. The darker side of modernity: Global futures, decolonial options. Durham \& London: Duke University Press

Pratt, Mary Louise. 1999. Arts of the Contact Zone. In David Bartholomae \& Anthony Petrosky (eds.) Ways of reading. 5th edn. New York: Bedford/St. Martin's. Internet Archive Wayback Machine. (accessed 1 September 2015).

Pratt, Mary Louise. 2001. I, Rigoberta Menchú and the 'culture wars.' In Arturo Arias (ed.) The Rigoberta Menchú controversy. With a response by David Stoll, 29-56. Minneapolis: Minnesota University Press.

Pratt, Mary Louise. 2008. Imperial eyes: Travel writing and transculturation. New York: Routledge. 